\title{
Neutral Amino Acid Transporter B(0)
}

National Cancer Institute

\section{Source}

National Cancer Institute. Neutral Amino Acid Transporter B(0). NCI Thesaurus. Code C118927.

Neutral amino acid transporter $\mathrm{B}(0)(541 \mathrm{aa}, \sim 57 \mathrm{kDa})$ is encoded by the human SLC1A5 gene. This protein is involved in neutral amino acid transport and as a receptor for select retroviruses. 